\title{
EFFECTS OF HAND ON EM ABSORPTION AND ANTENNA PERFORMANCES FOR INTERNAL HANDSET PIFA
}

\author{
M. R. I. Faruque, M. I. Hossain
}

Preliminary communication

The aim of this investigation is to analyse the effects of hand on electromagnetic (EM) absorption and antenna performances. The EM absorption is evaluated by using the specific absorption rate (SAR) in the human head and total absorbed power by the user in this paper. The antenna performance's parameters comprising radiation efficiency, total efficiency, gain and bandwidth are considered in this investigation. The analysis was performed using mobile phone with a human head and hand model in both cheek and tilt positions. The main part of the investigation is based on the finite-difference timedomain (FDTD) method. The results show that the SAR values are decreased and total absorbed power by user increased rapidly due to insertion of hand model. The user's hand also leads to degrade antenna's communication performance considerably. Moreover, the presented analysis provides some useful indication to design handset antenna considering hand effects.

Keywords: antenna; FDTD method; hand effects; human hand model; human head model; PIFA (Planar Inverted F Antenna); SAR

Djelovanje ruke na elektromagnetsku apsorpciju i funkcioniranje antene za interni PIFA ručni telefon

Prethodno priopćenje

Cilj ovog istraživanja je analizirati učinke ruke na elektromagnetsku (EM) apsorpciju i funkcioniranje antene. U radu se procjenjuje EM apsorpcija pomoću specifične brzine apsorpcije - specific absorption rate (SAR) u ljudskoj glavi i ukupne apsorbirane snage od strane korisnika. U radu se razmatraju parametri djelovanja antene uključujući učinkovitost zračenja, ukupnu učinkovitost, pojačanje i širinu frekvencijskog područja. Analiza je provedena pomoću mobilnog telefona položenog na obraz i s nagibom na obraz. Glavni dio istraživanja temelji se na finite-difference time-domain (FDTD) metodi. Rezultati pokazuju da su se SAR vrijednosti smanjile i da se ukupna snaga koju je korisnik apsorbirao brzo povećala zbog umetanja ručnog modela. Ruka korisnika također dovodi do znatnog smanjenja komunikacijskog učinka antene. Osim toga, predstavljena analiza daje neke korisne naznake za dizajn antene mobilnog telefona s obzirom na položaj ruke.

Ključne riječi: antena; FDTD metoda; učinci ruke; model za ruku čovjeka; model za glavu čovjeka; PIFA (planarna invertirana F antena); SAR

\section{Introduction}

The use of portable terminal devices like cellular phone is being widespread gradually and hence the number of cellular phone user is increasing dramatically. The antennas of the cellular devices receive and radiate electromagnetic (EM) energy of different frequency depending on the type of applications. The emitted EM energy from portable terminal device's antenna may lead to serious health risks $[1,2]$ since the EM energy can penetrate human body tissues and a part of this energy is absorbed in it $[3,4]$. The power absorption by human body tissue is usually evaluated in terms of specific absorption rate (SAR) [5]. The safety limits of the SAR values are imposed by the American National Standards Institute (ANSI) and International Commission on NonIonizing Radiation protection (ICNIRP) [6]. Inclusion of the hand model affects SAR values as well as antenna performances $[7 \div 10]$. The hand effects on antenna performances highly depend on the hand grip and palmhandset gap $[11,12]$. The user's hand causes shifting the resonance frequency [13], reducing the channel's data rate [14] and detuning the antenna input impedance [7, 13]. This also contributes to degrade the radiation efficiency and increase absorption loss [13]. In [14], an investigation of effects of hand phantom on planar inverted-F antenna (PIFA) and helical antenna was presented. The results indicated that hand phantom leads to affect antenna performances depending on the position of hand with respect to mobile phone antenna. In [15], an analysis of hand effects on the resonance characteristics of dual band PIFA was presented. The results showed that the hand phantom brought slight impedance matching deterioration for both GSM frequency bands. Additionally, presence of the user's hand leads to less conservative SAR values to the human head [16]. The human hand leads to reduce the SAR values to the head tissues, as it dispels a part of antenna radiated energy $[17,18]$. The effects of hand holding position on the EM interaction between mobile phone and human was investigated in [19]. The obtained results indicated that the SAR values remarkably change in consequence of the positioning of the mobile phone against the human head at different hand levels.

The objective of this investigation is to find out the impacts of the human hand on PIFA EM absorption characteristics and performances for two distinctive GSM frequency bands. Two parameters - SAR and total absorbed power are used to explain the EM absorption characteristic. The commonly used cheek and tilt position of talk mode are used to simulate the handset antenna with the user's head and hand phantoms. Moreover, the effects on the antenna performance parameters comprising radiation efficiency, bandwidth, and gain were investigated to evaluate the effects of hand phantom on antenna performances.

\section{Models and methods}

A dual band GSM $(0.9 \mathrm{GHz}$ and $1.8 \mathrm{GHz})$ planar inverted-F antenna (PIFA) [20] was used as handset antenna. The antenna consists of patch, ground, feed and shorting point. The antenna operated over dual GSM band has been selected to evaluate SAR in favour of talk mode of real use. A complete handset model consists of circuit board, display, battery, and plastic mobile casing was utilized. Tab. 1 shows the properties of mobile phone 
components. In this investigation, three-dimensional structural models were considered for head and hand phantom. The head phantom contains of several types of tissues: bone, brain, skin, muscle, fat, and eye (whole brain atlas website). The electrical properties of head and hand model are listed in Tab. 2.

Table 1 Electrical properties of the handset

\begin{tabular}{|l|c|c|}
\hline \multicolumn{1}{|c|}{ Handset materials } & $\begin{array}{c}\text { Conductivity } \\
(\mathrm{S} / \mathrm{m})\end{array}$ & $\begin{array}{c}\text { Relative } \\
\text { permittivity }\end{array}$ \\
\hline Circuit board (FR-4) & 0.05 & 4.9 \\
\hline LCD display & 0.02 & 3 \\
\hline Mobile cover & 0.027 & 3.5 \\
\hline
\end{tabular}

Table 2 Dielectric properties of the head and hand tissues

\begin{tabular}{|l|c|c|c|c|}
\hline \multirow{2}{*}{ Material } & \multicolumn{2}{|c|}{ Conductivity $(\mathrm{S} / \mathrm{m})$} & \multicolumn{2}{c|}{ Relative permittivity } \\
\cline { 2 - 5 } & $0.9 \mathrm{GHz}$ & $1.8 \mathrm{GHz}$ & $0.9 \mathrm{GHz}$ & $1.8 \mathrm{GHz}$ \\
\hline Muscle & 1.50 & 1.35 & 55.95 & 54.44 \\
\hline Skin & 1.48 & 1.33 & 49.60 & 46.90 \\
\hline Brain & 1.11 & 1.09 & 41.7 & 39.50 \\
\hline Bone & 0.12 & 0.11 & 4.83 & 4.48 \\
\hline Fat & 0.13 & 0.12 & 5.10 & 4.91 \\
\hline Eye & 2.03 & 1.99 & 68.6 & 65.3 \\
\hline Hand & 1 & 0.97 & 20 & 18.8 \\
\hline
\end{tabular}

The head and hand dielectric properties were set in accordance with the frequency of exposure. The head and hand dielectric properties were set in accordance with the frequency of exposure. The values relative permittivity and conductivity of dielectric material are chosen based on human tissue measurement data as described in [21]. To precisely illustrate the performance over broad frequency range dispersive models for all the dielectric materials were used for simulation [22]. The numerical simulation of SAR values and other antenna performance parameters were assessed espousing the Finite Integration Technique (FIT) method based on the Computer Simulation Technology (CST) Microwave Studio. FIT connected to Cartesian matrices in the time domain is computationally proportionate to the standard Finite Difference Time Domain (FDTD) strategy. FIT joined with Perfect Boundary Approximation (PBA) can keep up the helpful organized Cartesian lattices and allow an exact displaying of bended structures [23]. Fig. 1 demonstrates the simulation setup showing the relative positions of the portable handset, human head and hand. In lossy-Drude simulation model, $128 \times 128 \times 128$ cells domain was used with cell size $\Delta x=\Delta y=\Delta z=0.5 \mathrm{~mm}$. Here, the Drude model is more competent for the FDTD simulation for both the permeability and permittivity functions. This approach gives a substantially more extensive data transmission [25]. For the calculation of SAR values, the following standard formula was used:

$$
S A R=\frac{\sigma \cdot E^{2}}{\rho},
$$

Here $E$ expresses induced electric field strength $(\mathrm{V} / \mathrm{m})$, $\rho$ and $\sigma$ present density $\left(\mathrm{kg} / \mathrm{m}^{3}\right)$ and conductivity $(\mathrm{S} / \mathrm{m})$ of the tissue respectively. SAR values averaged over $1 \mathrm{~g}$ and $10 \mathrm{~g}$ of body tissues were evaluated espousing IEEE standard algorithm using the stimulated power $0.5 \mathrm{~W}$ (rms).

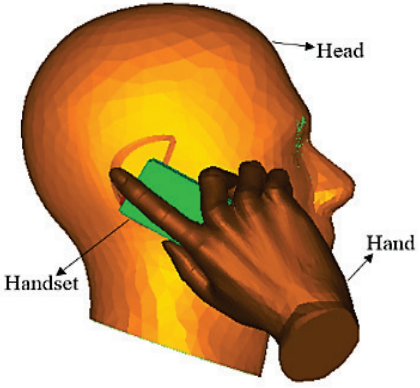

(a)

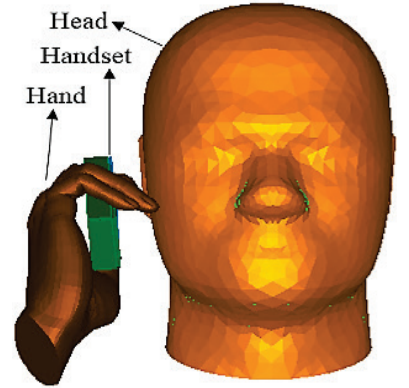

(b)
Figure 1 Simulation setup (a) front view (b) side view

\section{Results and discussions \\ 3.1 Effects of hand on SAR}

Two different talking position, cheek and tilt were studied in this investigation. The SAR and total absorbed power in the head was evaluated in all cases so that the effect of hand could be separated clearly.

\subsubsection{Cheek position analysis}

In cheek position analysis, three different distances (16 mm, $18 \mathrm{~mm}$ and $20 \mathrm{~mm}$ ) of cellular phone from head axis were taken both for without the hand and with hand configurations. The SAR values along with its $3 \mathrm{D}$ surface distribution are shown in Tab. 3 for different cheek positions. Moreover, Fig. 2 indicates the total absorbed power values by the user. In a cheek position of the cell phone with $16 \mathrm{~mm}$ apart from the user's head axis, the SAR reduction occurs $27.2 \%$ for $1 \mathrm{~g}$ averaging $(26.7 \%$ for $10 \mathrm{~g}$ of tissue) at lower GSM frequency band and 2.7 $\%$ for $1 \mathrm{~g}(2.1 \%$ for $10 \mathrm{~g}$ of tissue) at the upper GSM frequency band. It is observed that the SAR values at 1.8 $\mathrm{GHz}$ are less affected than those at $0.9 \mathrm{GHz}$. Moreover, cheek position of $18 \mathrm{~mm}$ contributes to reduce the SAR $27.6 \%$ for $1 \mathrm{~g}$, averaging (27.7 \% for $10 \mathrm{~g}$ of tissue) at $0.9 \mathrm{GHz}$ and $6.21 \%$ for $1 \mathrm{~g}(5.7 \%$ for $10 \mathrm{~g})$ at $1.8 \mathrm{GHz}$. In addition, cheek position of $20 \mathrm{~mm}$ contributes to reduce the SAR $29.8 \%$ for $1 \mathrm{~g}$, averaging $(29.7 \%$ for 10 $\mathrm{g}$ of tissue) at $0.9 \mathrm{GHz}$ and $0.94 \%$ for $1 \mathrm{~g}(5.97 \%$ for 10 $\mathrm{g})$ at $1.8 \mathrm{GHz}$. Increase in phone distance from the user's head reduces the SAR values in every case. It is also important to mention that the percentage of SAR reduction due to user's hand is not affected greatly for lower frequency band for three different configurations. But the SAR reduction due to user's hand increases with increasing phone distance at $1.8 \mathrm{GHz}$. The inclusion of hand model prompts to enlarge total absorbed power in all cases. In case of cheek position with $16 \mathrm{~mm}$ phone distance, power absorbed by the user was $32.2 \%$ for with hand configuration and $14.6 \%$ for without hand configuration at $0.9 \mathrm{GHz}$. On the other hand, the power absorbed by the user $66.6 \%$ and $26.6 \%$ for with and without hand configuration, respectively at $1.8 \mathrm{GHz}$ considering $16 \mathrm{~mm}$ cell phone distance. The results from $18 \mathrm{~mm}$ and $20 \mathrm{~mm}$ cell phone distance also provide similar tendency as compared with the results from 16 $\mathrm{mm}$ distance configuration. The hand phantom causes more than two times increment of total absorbed power compared to without hand configurations in all cases. 


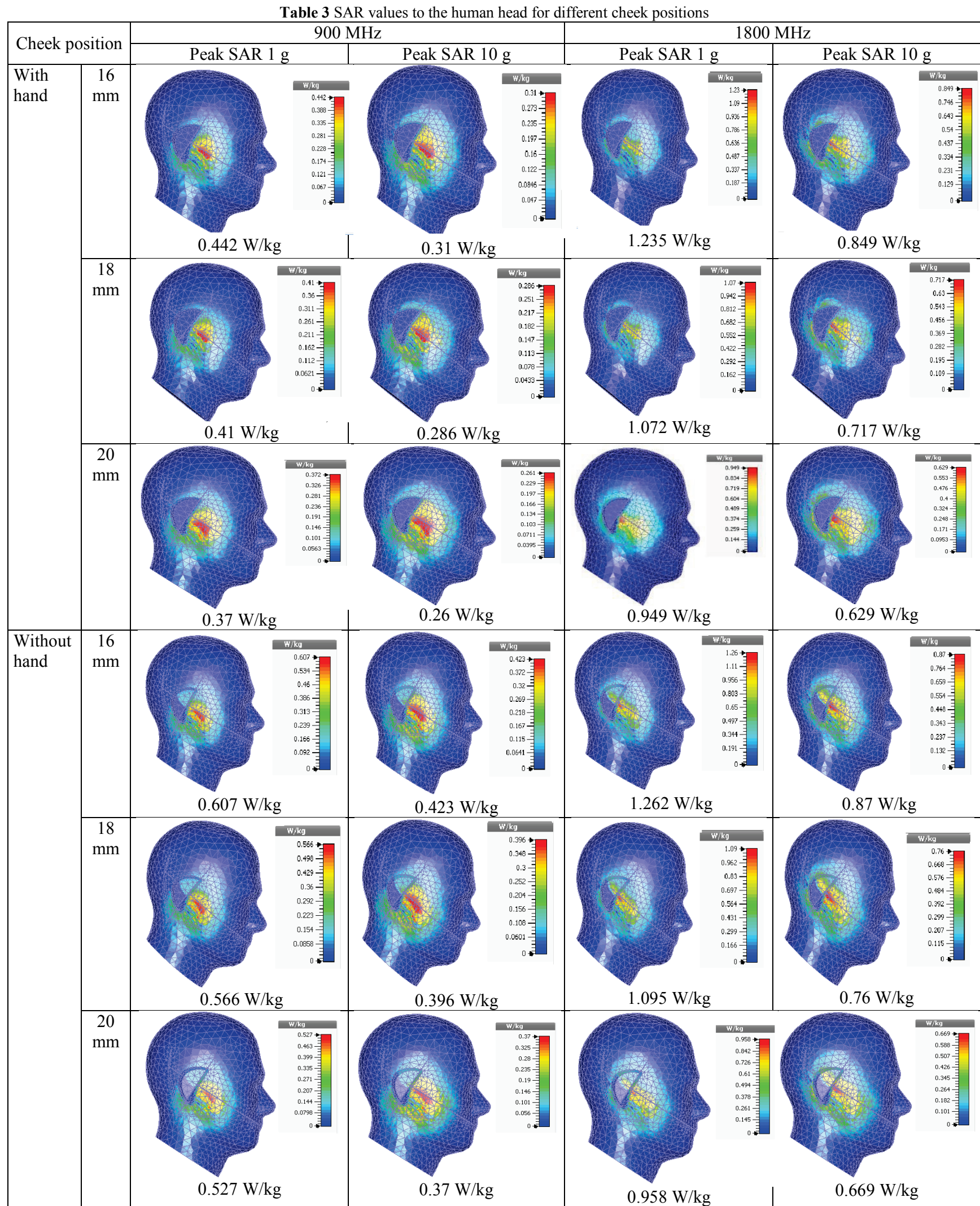

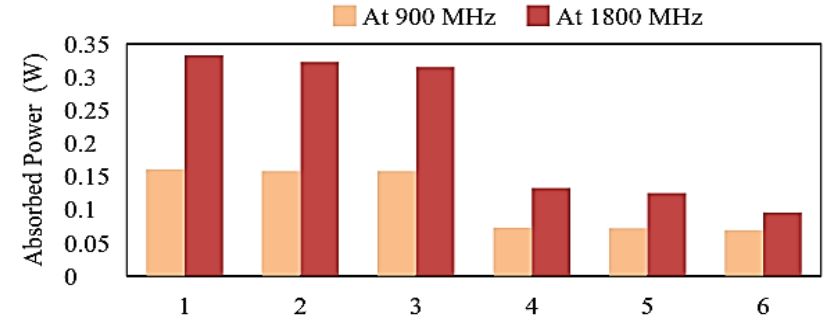

Figure 2 Total absorbed power by head for different cheek position

\subsubsection{Tilt position analysis}

In this section, 15 degree and 30 degree tilt position of phone were considered for both with hand and without hand configuration. Three distance configurations (16 $\mathrm{mm}, 18 \mathrm{~mm}$ and $20 \mathrm{~mm}$ ) were also used in tilt position analysis. The results of the SAR values have been listed in Tabs. 4, 5 and 6. In case of different tilt position, the 
SAR values decline due to the presence of the user's hand at $0.9 \mathrm{GHz}$, but the $\mathrm{SAR}$ values rise at $1.8 \mathrm{GHz}$. For 15 degree tilt position of $16 \mathrm{~mm}$ distance, $27.2 \%$ for $1 \mathrm{~g}(27$ $\%$ for $10 \mathrm{~g}$ ) SAR reduction can be found at $0.9 \mathrm{GHz}$. Instead, the SAR rises $5.14 \%$ for $1 \mathrm{~g}(2.15 \%$ for $10 \mathrm{~g})$ at $1.8 \mathrm{GHz}$. In addition, 30 degree tilt position of $16 \mathrm{~mm}$ distance configuration contributes to decrease the SAR $26.5 \%$ for $1 \mathrm{~g}(31.8 \%$ for $10 \mathrm{~g})$ at $0.9 \mathrm{GHz}$ and increase the SAR $5.8 \%$ for $1 \mathrm{~g}(4.4 \%$ for $10 \mathrm{~g})$ at $1.8 \mathrm{GHz}$.

Sequentially, $28.2 \%$ reduction and $3 \%$ (for $1 \mathrm{~g}$ ) increment in the SAR are marked at $0.9 \mathrm{GHz}$ and $1.8 \mathrm{GHz}$ respectively for 15 degree tilt position of $18 \mathrm{~mm}$ distance configuration. 30 degree tilt position of $18 \mathrm{~mm}$ distance configuration contributes to decrease the SAR $22.4 \%$ for $1 \mathrm{~g}$ at $0.9 \mathrm{GHz}$ and increase the SAR $5.8 \%$ for $1 \mathrm{~g}$ at 1.8 $\mathrm{GHz}$. The results from tilt positions of $20 \mathrm{~mm}$ distance configuration show identical tendency as two other configurations. The results indicate that the SAR values decrease significantly with increasing tilt angle. Moreover, $8.5 \%(1 \mathrm{~g})$ reduction in the SAR is obtained from $16 \mathrm{~mm}$ to $18 \mathrm{~mm}$ distance and also $18 \mathrm{~mm}$ to $20 \mathrm{~mm}$ distance configuration in case of 15 degree tilt position at $0.9 \mathrm{GHz}$. The SAR decreases $14.4 \%$ ( $1 \mathrm{~g}$ ) from $16 \mathrm{~mm}$ to $18 \mathrm{~mm}$ and $11.2 \%(1 \mathrm{~g})$ from $18 \mathrm{~mm}$ to $20 \mathrm{~mm}$ in case of 15 degree tilt position at $1.8 \mathrm{GHz}$ respectively.

Table 4 SAR values to the human head for different tilt positions (16 mm)

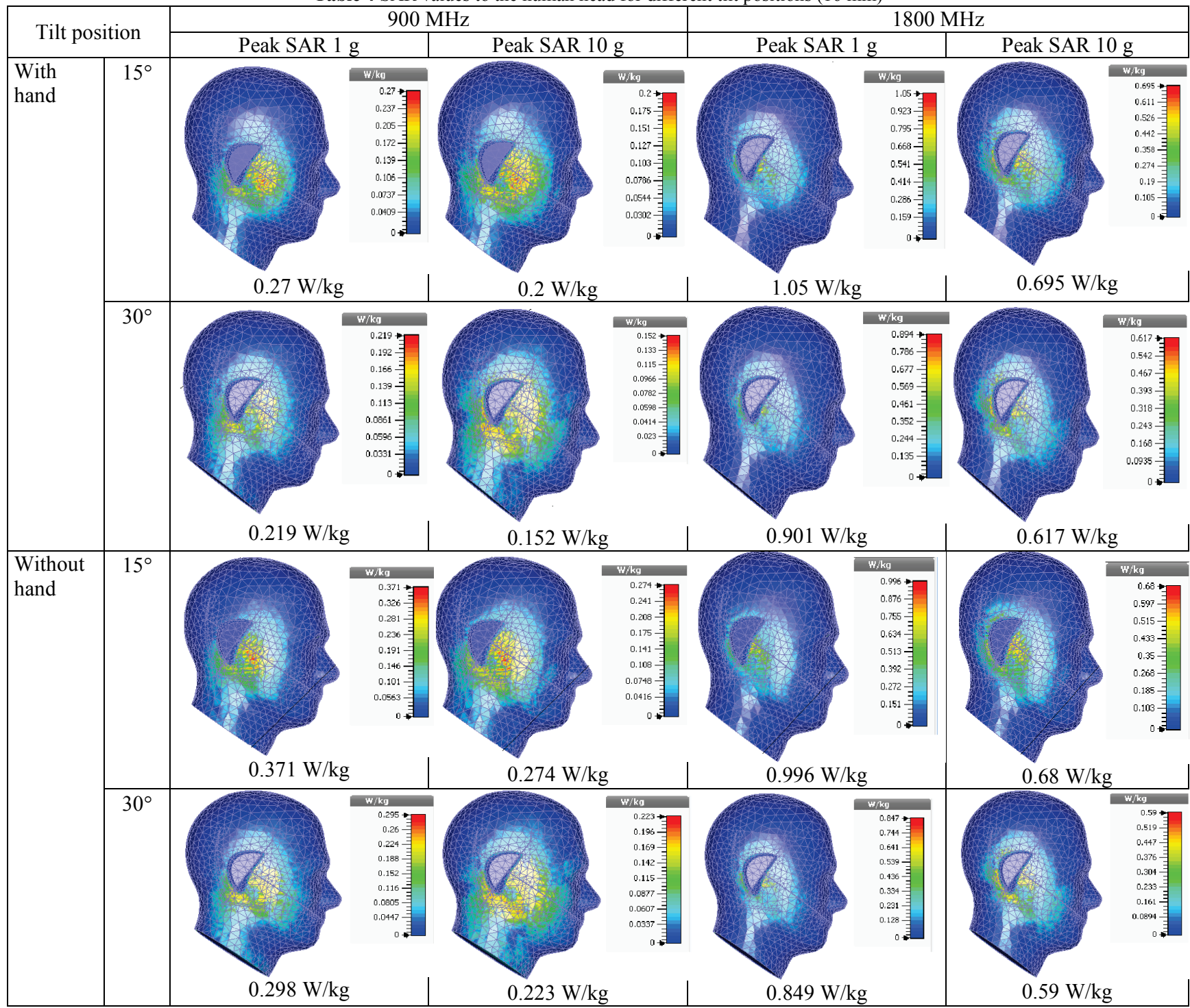

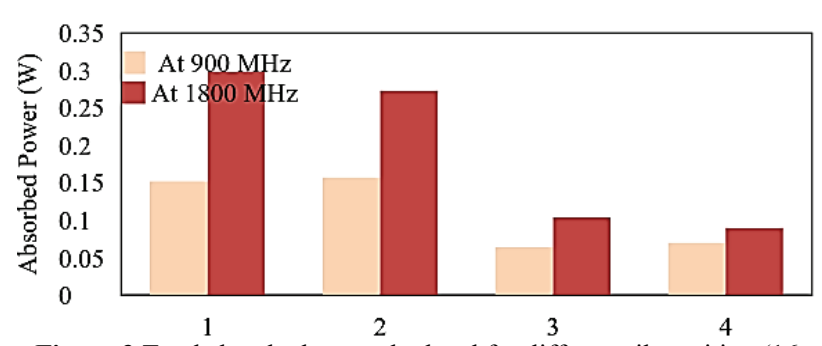

Figure 3 Total absorbed power by head for different tilt position (16 $\mathrm{mm})$

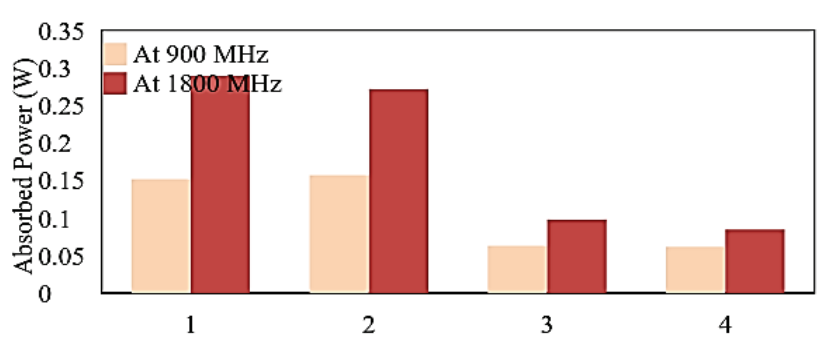

Figure 4 Total absorbed power by head for different tilt position (18 $\mathrm{mm}$ ) 


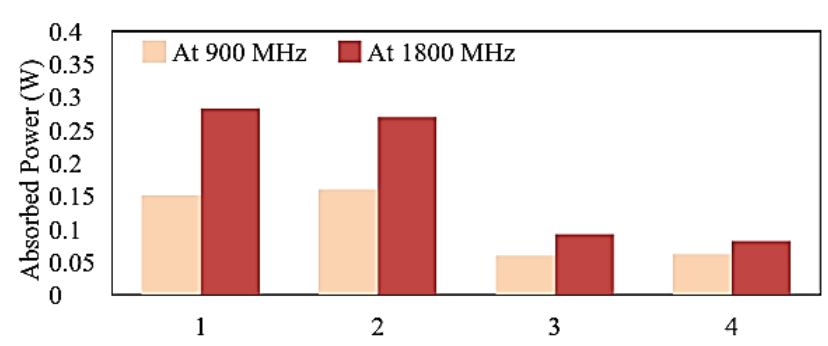

Figure 5 Total absorbed power by head for different tilt position (20 $\mathrm{mm}$ )

Figs. 3, 4, and 5 indicate the total absorbed power by the user for $16 \mathrm{~mm}, 18 \mathrm{~mm}$, and $30 \mathrm{~mm}$ distance configurations, respectively. Tilt position analysis shows that the hand phantom causes more than two times increment of total absorbed power compared to without hand configurations. For 15 degree tilt position of $16 \mathrm{~mm}$, the total power absorbed by user increases $17.6 \%$ at 0.9 $\mathrm{GHz}$ and $38.8 \%$ at $1.8 \mathrm{GHz}$. In addition, 30 degree tilt position with hand of $16 \mathrm{~mm}$ contributes to increase the total absorbed power $17.4 \%$ at the lower frequency band and $36.6 \%$ at the upper frequency band. The $18 \mathrm{~mm}$ and $20 \mathrm{~mm}$ distance configuration also show same tendency as $16 \mathrm{~mm}$ distance configuration.

\subsection{Effects of hand on Antenna Performances}

The effects of hand on antenna performances were evaluated comprising different performance parameters: radiation efficiency, total efficiency, bandwidth, and gain. Also, the results related to the antenna performance have been presented in two categories in this paper.

\subsubsection{Cheek position analysis}

The performance parameters of mobile phone were calculated for three different cheek positions (16 mm, 18 $\mathrm{mm}$ and $20 \mathrm{~mm}$ ).

\begin{tabular}{|c|c|c|c|c|c|c|}
\hline \multirow{2}{*}{\multicolumn{2}{|c|}{ Tilt position }} & \multicolumn{2}{|c|}{$900 \mathrm{MHz}$} & \multicolumn{3}{|c|}{$1800 \mathrm{MHz}$} \\
\hline & & Peak SAR $1 \mathrm{~g}$ & Peak SAR $10 \mathrm{~g}$ & Peak SAR $1 \mathrm{~g}$ & Peak SAR 10 & \\
\hline $\begin{array}{l}\text { With } \\
\text { hand }\end{array}$ & $15^{\circ}$ & $0.247 \mathrm{~W} / \mathrm{kg}$ & (3) & $0.899 \mathrm{~W} / \mathrm{kg}$ & $\begin{array}{l}\text { } \\
0.61 \mathrm{~W} / \mathrm{kg} \\
\end{array}$ & 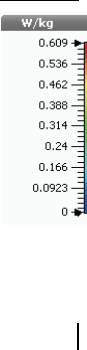 \\
\hline & $30^{\circ}$ & $0.194 \mathrm{~W} / \mathrm{kg}$ & $\begin{array}{l}0.138 \mathrm{~W} / \mathrm{kg} \\
0.13\end{array}$ & $0.798 \mathrm{~W} / \mathrm{kg}$ & 0.558 W/kg & 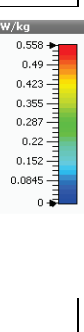 \\
\hline $\begin{array}{l}\text { Without } \\
\text { hand }\end{array}$ & $15^{\circ}$ & $0.344 \mathrm{~W} / \mathrm{kg}$ & $0.255 \mathrm{~W} / \mathrm{kg}$ & $0.872 \mathrm{~W} / \mathrm{kg}$ & $0.596 \mathrm{~W} / \mathrm{kg}$ & 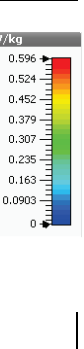 \\
\hline & $30^{\circ}$ & $0.25 \mathrm{~W} / \mathrm{kg}$ & $0.187 \mathrm{~W} / \mathrm{kg}$ & $0.748 \mathrm{~W} / \mathrm{kg}$ & 0.52 W/kg & 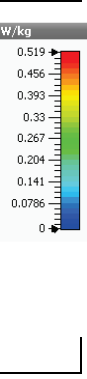 \\
\hline
\end{tabular}




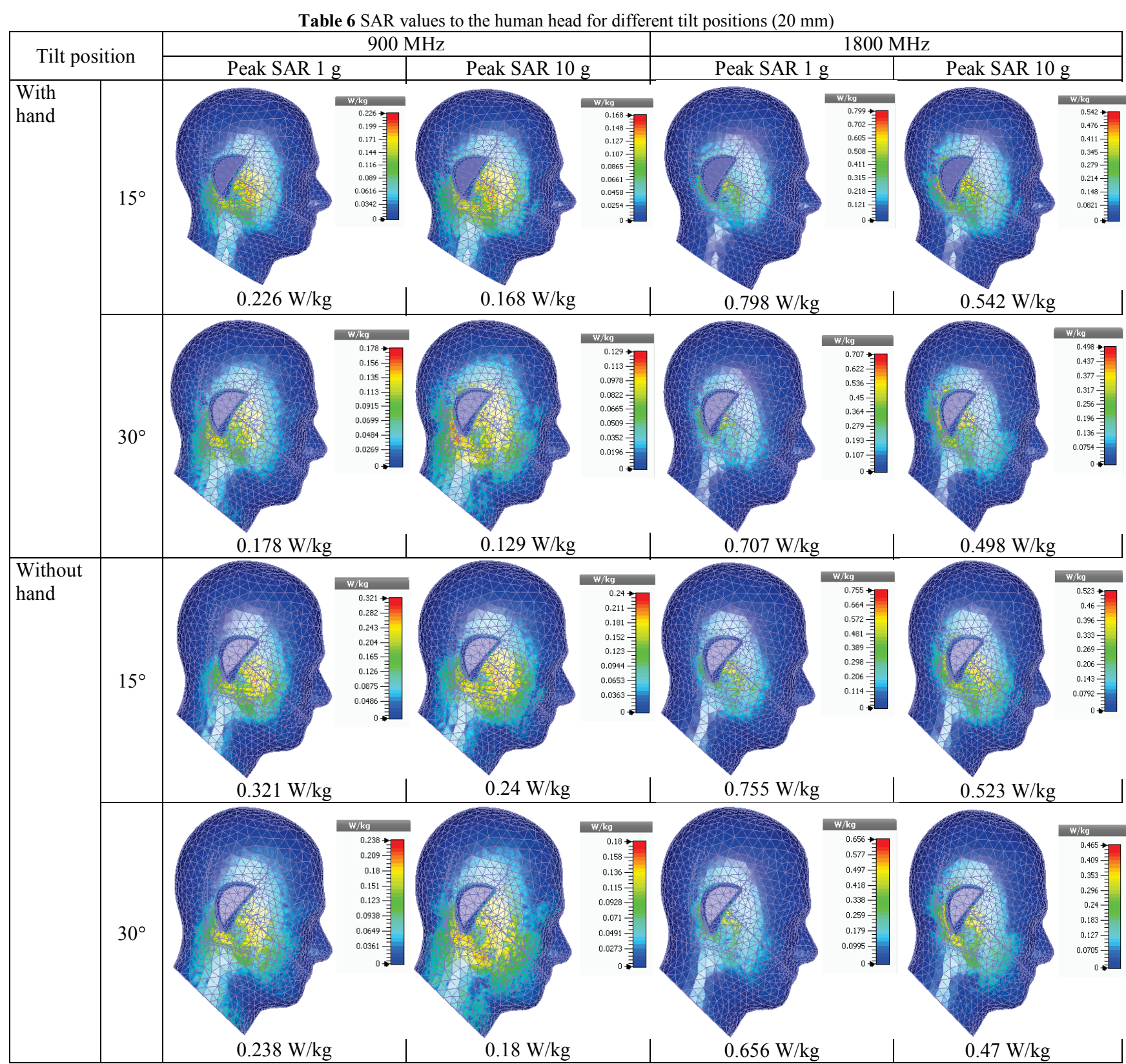

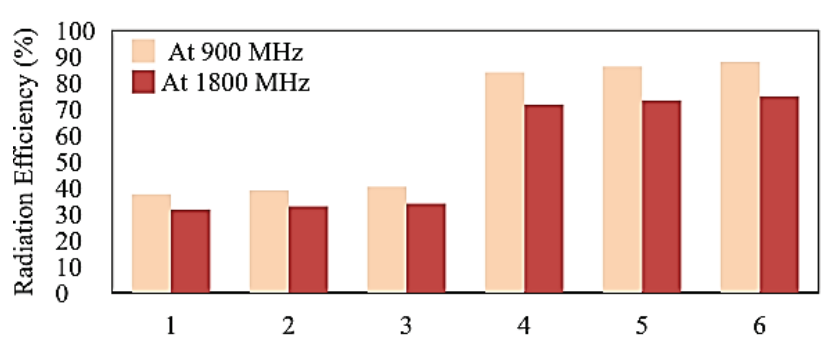

Figure 6 Radiation efficiency of mobile phone for cheek positions

The radiation efficiency, total efficiency, gain and bandwidth decrease due to the insertion of hand model for all configurations of cheek position. Fig. 6 and Fig. 7 represent the values of radiation efficiency and total efficiency respectively for cheek positions. At $0.9 \mathrm{GHz}$, the radiation efficiency decreases $44.4 \%$ for $16 \mathrm{~mm}$ phone distance, $47.3 \%$ for $18 \mathrm{~mm}$ phone distance and $47.5 \%$ for $20 \mathrm{~mm}$ phone distance. Additionally, the degradation of radiation efficiencies is $40.1 \%, 40.4 \%$ and $40.9 \%$ for $16 \mathrm{~mm}, 18 \mathrm{~mm}$ and $20 \mathrm{~mm}$ cell phone distance respectively at $1.8 \mathrm{GHz}$.

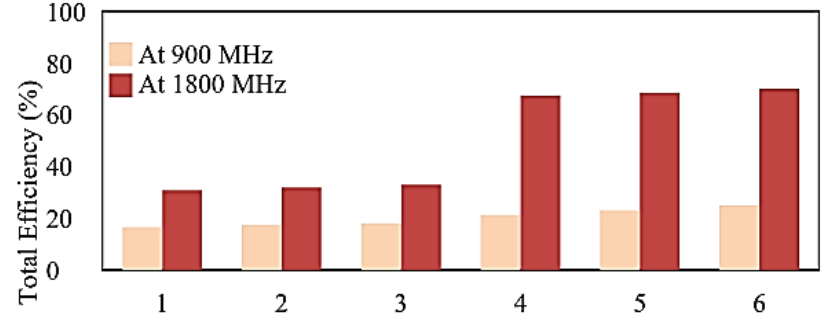

Figure 7 Total efficiency of mobile phone for cheek positions.

Moreover, the antenna gain degrades $2.83 \mathrm{~dB}, 2.82$ $\mathrm{dB}, 2.78$ for $16 \mathrm{~mm}, 18 \mathrm{~mm}$ and $20 \mathrm{~mm}$ phone distance configuration as shown in Table 7 at the lower frequency band respectively. Sequentially, $5.1 \mathrm{~dB}, 4.98 \mathrm{~dB}, 4.97 \mathrm{~dB}$ antenna gain degradation occur for $16 \mathrm{~mm}, 18 \mathrm{~mm}$ and 20 $\mathrm{mm}$ phone distance at the upper frequency band respectively. The frequency bandwidth of the antenna for $16 \mathrm{~mm}$ distance is reduced $3.6 \mathrm{MB}$ at $0.9 \mathrm{GHz}$ and $13 \mathrm{MB}$ at $1.8 \mathrm{GHz}$ after using the user's hand. For other distance configurations, the bandwidth is also reduced by few MB. The bandwidth reduction is more significant at the upper 
frequency band as compared with the lower frequency band.

Table 7 Gain and Bandwidth of mobile phone for cheek positions

\begin{tabular}{|l|c|c|c|c|c|}
\hline \multirow{2}{*}{\begin{tabular}{c}
\multirow{2}{*}{$\begin{array}{c}\text { Cheek } \\
\text { position } \\
(\mathrm{mm})\end{array}$} \\
\cline { 2 - 6 }
\end{tabular}} & $\begin{array}{c}\text { Gain } \\
(\mathrm{dB})\end{array}$ & $\begin{array}{c}\text { Bandwidth } \\
(\mathrm{MHz})\end{array}$ & $\begin{array}{c}\text { Gain } \\
(\mathrm{dB})\end{array}$ & $\begin{array}{c}\text { Bandwidth } \\
(\mathrm{MHz})\end{array}$ \\
\hline \multirow{2}{*}{$\begin{array}{l}\text { With } \\
\text { hand }\end{array}$} & 16 & 1.177 & 32.4 & 0.691 & 143.8 \\
\cline { 2 - 6 } & 18 & 1.373 & 30 & 0.798 & 140 \\
\cline { 2 - 6 } & 20 & 1.557 & 29 & 0.801 & 138 \\
\hline \multirow{2}{*}{$\begin{array}{l}\text { Without } \\
\text { hand }\end{array}$} & 16 & 4.007 & 36 & 5.793 & 157 \\
\cline { 2 - 6 } & 18 & 4.188 & 36.65 & 5.785 & 156 \\
\cline { 2 - 6 } & 20 & 4.335 & 37 & 5.776 & 155 \\
\hline
\end{tabular}

\subsubsection{Tilt position analysis}

The results from tilt position analysis indicate that the radiation efficiency, total efficiency, gain and bandwidth degrade owing to insertion of the hand phantom as the cheek position analysis. The radiation efficiency and total efficiency are reduced $41.5 \%$ and $8.7 \%$ respectively for 15 degree tilt configuration at $0.9 \mathrm{GHz}$ in case of $16 \mathrm{~mm}$ phone distance (as shown in Figs. 8 and 9). Sequentially, $40.8 \%$ and $35.4 \%$ degradation can be found for the radiation efficiency and total efficiency respectively at 1.8 $\mathrm{GHz}$ for 15 degree tilt position of $16 \mathrm{~mm}$ distance configuration. The tilt position analysis with $18 \mathrm{~mm}$ (as indicated in Figs. 10 and 11) and $20 \mathrm{~mm}$ (as shown in Figs. 12 and 13) cell phone distance provide identical tendency as $16 \mathrm{~mm}$ distance configuration. Additionally, the antenna gain degrades $1.6 \mathrm{~dB}$ at $0.9 \mathrm{GHz}$ and $3.95 \mathrm{~dB}$ at $1.8 \mathrm{GHz}$ for 15 degree tilt position of $16 \mathrm{~mm}$ as indicated in Tab. 8. The bandwidth of antenna falls 2.28 $\mathrm{MB}$ at the lower frequency band and 13.6 $\mathrm{MB}$ at the upper frequency band for 15 degree tilt position of $16 \mathrm{~mm}$ configuration.

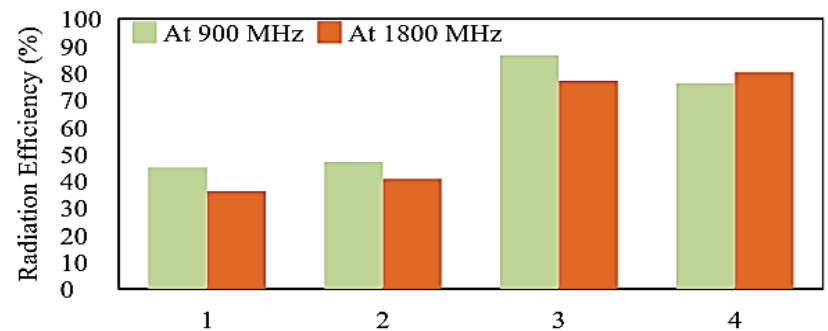

Figure 8 Radiation efficiency of mobile phone for tilt positions (16 mm)

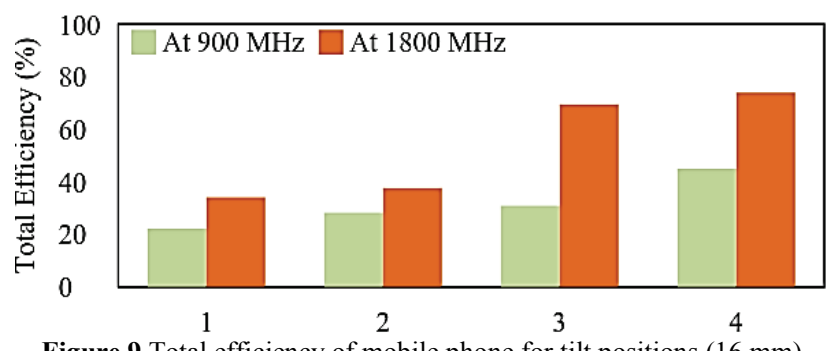

Figure 9 Total efficiency of mobile phone for tilt positions $(16 \mathrm{~mm})$

Likewise, the antenna bandwidth degrades 16.7 MB at $0.9 \mathrm{GHz}$ and $13.6 \mathrm{MB}$ at $1.8 \mathrm{GHz}$ considering 30 degree tilt position of $16 \mathrm{~mm}$ distance. The radiation efficiency, total efficiency and gain improve little bit due to increase in cell phone distance. The results of gain and bandwidth from tilt position analysis with $18 \mathrm{~mm}$ (as indicated in Tab. 9) and $20 \mathrm{~mm}$ (as shown in Tab. 10) cell phone distance provide identical tendency as $16 \mathrm{~mm}$ distance configuration. With the variation of tilt angle, antenna performance's parameters show little variation.

Table 8 Gain and Bandwidth of mobile phone for tilt positions (16 mm)

\begin{tabular}{|l|c|c|c|c|c|}
\hline \multirow{2}{*}{ Tilt position } & \multicolumn{2}{|c|}{$900 \mathrm{MHz}$} & \multicolumn{2}{c|}{$1800 \mathrm{MHz}$} \\
\cline { 3 - 6 } \multicolumn{2}{|c|}{} & $\begin{array}{c}\text { Gain } \\
(\mathrm{dB})\end{array}$ & $\begin{array}{c}\text { Bandwidth } \\
(\mathrm{MHz})\end{array}$ & $\begin{array}{c}\text { Gain } \\
(\mathrm{dB})\end{array}$ & $\begin{array}{c}\text { Bandwidth } \\
(\mathrm{MHz})\end{array}$ \\
\hline \multirow{3}{*}{ With hand } & $15^{\circ}$ & 1.218 & 33.22 & 1.098 & 135.4 \\
\cline { 2 - 6 } & $30^{\circ}$ & 0.713 & 33.83 & 1.171 & 136.7 \\
\hline $\begin{array}{l}\text { Without } \\
\text { hand }\end{array}$ & $15^{\circ}$ & 2.829 & 35.5 & 5.596 & 149 \\
\cline { 2 - 6 } & $30^{\circ}$ & 1.633 & 36.91 & 5.05 & 153.4 \\
\hline
\end{tabular}

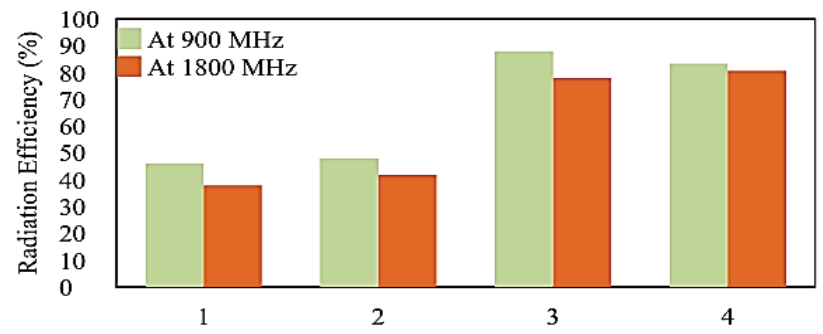

Figure 10 Radiation efficiency of mobile phone for tilt positions (18 $\mathrm{mm})$

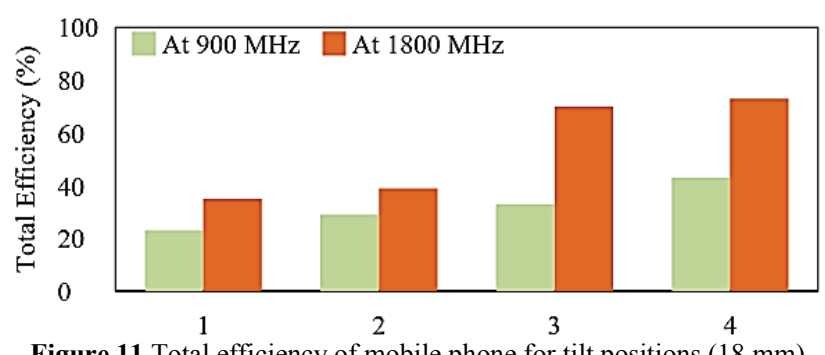

Figure 11 Total efficiency of mobile phone for tilt positions $(18 \mathrm{~mm})$

Table 9 Gain and Bandwidth of mobile phone for tilt positions (18 mm)

Table 9 Gain and Bandwidth of mobile phone for tilt positions $(18 \mathrm{~mm})$
\begin{tabular}{|l|c|c|c|c|c|}
\hline \multirow{2}{*}{ Tilt position } & \multicolumn{2}{|c|}{$900 \mathrm{MHz}$} & \multicolumn{2}{c|}{$1800 \mathrm{MHz}$} \\
\cline { 3 - 6 } \multicolumn{2}{|c|}{} & $\begin{array}{c}\text { Gain } \\
(\mathrm{dB})\end{array}$ & $\begin{array}{c}\text { Bandwidth } \\
(\mathrm{MHz})\end{array}$ & $\begin{array}{c}\text { Gain } \\
(\mathrm{dB})\end{array}$ & $\begin{array}{c}\text { Bandwidth } \\
(\mathrm{MHz})\end{array}$ \\
\hline \multirow{2}{*}{$\begin{array}{l}\text { With } \\
\text { hand }\end{array}$} & $15^{\circ}$ & 1.347 & 35 & 1.077 & 140 \\
\cline { 2 - 6 } & $30^{\circ}$ & 0.8411 & 35 & 1.37 & 146 \\
\hline \multirow{2}{*}{$\begin{array}{l}\text { Without } \\
\text { hand }\end{array}$} & $15^{\circ}$ & 2.954 & 35 & 5.552 & 152 \\
\cline { 2 - 6 } & $30^{\circ}$ & 1.995 & 37 & 4.988 & 151 \\
\hline
\end{tabular}

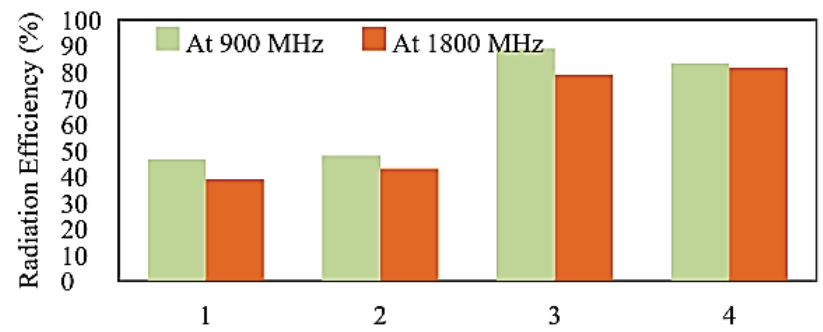

Figure 12 Radiation efficiency of mobile phone for tilt positions (20 $\mathrm{mm})$

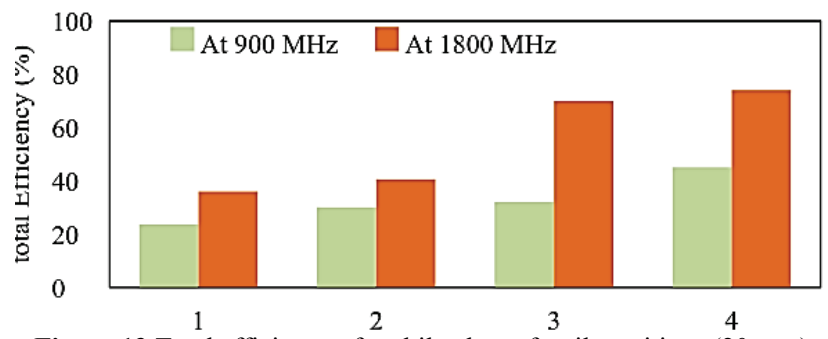

Figure 13 Total efficiency of mobile phone for tilt positions $(20 \mathrm{~mm})$ 
Table 10 Gain and Bandwidth of mobile phone for tilt positions (20 $\mathrm{mm})$

\begin{tabular}{|l|c|c|c|c|c|}
\hline \multirow{2}{*}{ Tilt position } & \multicolumn{2}{|c|}{$900 \mathrm{MHz}$} & \multicolumn{2}{c|}{$1800 \mathrm{MHz}$} \\
\cline { 3 - 6 } \multicolumn{2}{|c|}{} & $\begin{array}{c}\text { Gain } \\
(\mathrm{dB})\end{array}$ & $\begin{array}{c}\text { Bandwidth } \\
(\mathrm{MHz})\end{array}$ & $\begin{array}{c}\text { Gain } \\
(\mathrm{dB})\end{array}$ & $\begin{array}{c}\text { Bandwidth } \\
(\mathrm{MHz})\end{array}$ \\
\hline $\begin{array}{l}\text { With } \\
\text { hand }\end{array}$ & $15^{\circ}$ & 1.454 & 35 & 1.194 & 140 \\
\cline { 2 - 6 } & $30^{\circ}$ & 0.88 & 36 & 1.546 & 145 \\
\hline \multirow{2}{*}{$\begin{array}{l}\text { Without } \\
\text { hand }\end{array}$} & $15^{\circ}$ & 3.58 & 35 & 6.5 & 150 \\
\cline { 2 - 6 } & $30^{\circ}$ & 1.99 & 34 & 4.97 & 151.4 \\
\hline
\end{tabular}

\section{Conclusion}

In this study, the effects of the human hand on the SAR values towards human head have been presented using mobile handset of the dual band PIFA antenna. The effects of hand phantom on the antenna performances have been investigated also. The cheek position results show that the user's hand causes the SAR reduction greatly at the lower frequency band and slightly at the upper frequency band. But the results from the tilt position analysis indicate that the SAR values decrease considerably at $0.9 \mathrm{GHz}$ and increase slightly at $1.8 \mathrm{GHz}$. The maximum SAR reduction was $27.2 \%$ due to user's hand in cheek and tilt position. Moreover, the hand phantom contributed to increase the total power absorption more than two times in both cheek and tilt position talk mode.

The hand phantom degrades the antenna performances greatly. The degradation in radiation efficiency is more than $40 \%$ both for cheek and tilt positions. In addition, gain degradation has occurred where the gain at the upper frequency band decreases extremely in both cheek and tilt position talk mode. To design a handset antenna, hand phantom effect should be taken into consideration. Further study may be extended to design a mobile phone antenna with minimal hand effects by using adaptive matching of the antenna input impedance. This can cancel the additional reflection loss caused by the detuning of the input impedance.

\section{References}

[1] Blackman, C. F.; Blank, M.; Kundi, M.; Sage, C.; Carpenter, D. O.; Davanipour, Z.; Gee, D.; Hardell, L.; Johansson, O.; Lai, H. The Bioinitiative Report-A Rationale for a Biologically-based Public Exposure Standard for Electromagnetic Fields (ELF and RF). // http://www.bioinitiative.org/report/docs/report.pdf (01.03.2007)

[2] Lloyd-Morgan, L.; Barris, E.; Newton, J.; O'Connor, E.; Philips, A.; Philips, G.; Rees, C.; Stein, B. Cell-phones and brain tumours: 15 reasons for concern. Science, spin and the truth behind interphone. // The Radiation Research Trust. (2009), pp. 1-38.

[3] Hossain, M. I.; Faruque, M. R. I.; Islam, M. T.; Hanafi, N. H. M. Application of Auxiliary Antenna Elements for SAR Reduction in the Human Head. // Advanced Materials Research. 974, (2014), pp. 288-292.

https://doi.org/10.4028/www.scientific.net/AMR.974.288

[4] Martinez-Burdalo, M.; Martin, A.; Anguiano, M.; Villar, R.; Comparison of FDTD-calculated specific absorption rate in adults and children when using a mobile phone at 900 and $1800 \mathrm{MHz}$. // Physics in medicine and biology. 49, 2(2004), pp. 345. https://doi.org/10.1088/0031-9155/49/2/011

[5] Faruque, M. R. I.; Islam, M. T.; Misran, N. Analysis of electromagnetic absorption in mobile phones using metamaterials. // Electromagnetics. 31, 3(2011), pp. 215232. https://doi.org/10.1080/02726343.2011.558457

[6] Fung, L. C.; Leung, S. W.; Chan, K. H. An investigation of the SAR reduction methods in mobile phone applications. // Proceeding of the IEEE Int. Symposium on Electromagnetic Compatibility / EMC 2002, pp. 656-661. https://doi.org/10.1109/ISEMC.2002.1032669

[7] Valkonen, R.; Ilvonen, J.; Rasilainen, K.; Holopainen, J.; Icheln, C.; Vainikainen, P. Avoiding the interaction between hand and capacitive coupling element based mobile terminal antenna. // Proceedings of the 5th European Conference on Antennas and Propagation, IEEE 2011, pp. 2781-2785

[8] Kivekas, O.; Ollikainen, J.; Lehtiniemi, T.; Vainikainen, P. Bandwidth, SAR, and efficiency of internal mobile phone antennas. // IEEE Transactions on Electromagnetic Compatibility. 46, 1(2004), pp. 71-86. https://doi.org/10.1109/TEMC.2004.823613

[9] Yu, W.; Yang, S.; Tang, C-L.; Tu, D. Accurate simulation of the radiation performance of a mobile slide phone in a hand-head position. // IEEE Antennas and Propagation Magazine. 52, 2(2010), pp. 168-177. https://doi.org/10.1109/MAP.2010.5525613

[10] Ilvonen, J.; Kivekas, O.; Holopainen, J.; Valkonen, R.; Rasilainen, K.; Vainikainen, P. Mobile terminal antenna performance with the user's hand: Effect of antenna dimensioning and location. // IEEE Antennas and Wireless Propagation Letters. 10, (2011), pp. 772-775. https://doi.org/10.1109/LAWP.2011.2163290

[11] Pelosi, M.; Franek, O.; Knudsen, M. B.; Christensen, M.; Pedersen, G. F. A grip study for talk and data modes in mobile phones. // IEEE Transaction on Antennas and Propagation. 57, 4(2009), pp. 856-865. https://doi.org/10.1109/TAP.2009.2014590

[12] Pelosi, M.; Franek, O.; Knudsen, M. B.; Pedersen, G. F.; Andersen, J. B. Antenna proximity effects for talk and data modes in mobile phones. // IEEE Antennas and Propagation Magazine. 52, 3(2010), pp. 15-27. https://doi.org/10.1109/MAP.2010.5586570

[13] Plicanic, V.; Lau, B. K.; Ying, Z. Performance of a multiband diversity antenna with hand effects. // Proceeding of the IEEE Int. Workshop on Antenna Technology, IEEE 2008, pp. 478-481. https://doi.org/10.1109/IWAT.2008.4511395

[14] Li, C. H.; Ofli, E.; Chavannes, N.; Kuster, N. Effects of hand phantom on mobile phone antenna performance. // IEEE Transactions on Antennas and Propagation. 57, 9(2009), pp. 2763-2770. https://doi.org/10.1109/TAP.2009.2027081

[15] Vehovský, R.; Pokorný, M.; Pitra, K. User Hand Influence on Properties of a Dual-Band PIFA Antenna. // Radioengineering. 23, 3(2014), pp. 819-823.

[16] Li, C-H.; Douglas, M.; Ofli, E.; Derat, B.; Gabriel, S.; Chavannes, N.; Kuster, N. Influence of the hand on the specific absorption rate in the head. // IEEE Transactions on Antennas and Propagation. 60, 2(2012), pp. 1066-1074. https://doi.org/10.1109/TAP.2011.2173102

[17] Okoniewski, M.; Stuchly, M. A. A study of the handset antenna and human body interaction. // IEEE Transactions on Microwave Theory and Techniques. 44, 10(1996), pp. 1855-1864. https://doi.org/10.1109/22.539944

[18] Gandhi, O. P. Some numerical methods for dosimetry: extremely low frequencies to microwave frequencies. // Radio Science. 30, 1(1995), pp. 161-177. https://doi.org/10.1029/94RS01158

[19] Al-Mously, S. I.; Abousetta, M. M. Anticipated impact of handhold position on the electromagnetic interaction of different antenna types/positions and a human in cellular communications. // International Journal of Antennas and 
Propagation. 2008, Article ID 102759, (2009), pp. 22. https://doi.org/10.1155/2008/102759

[20] Hossain, M. I.; Faruque, M. R.; Islam, M. T. Analysis on the effect of the distances and inclination angles between human head and mobile phone on SAR. // Progress in biophysics and molecular biology. 119, 2(2015), pp. 103110. https://doi.org/10.1016/j.pbiomolbio.2015.03.008

[21] Fukunaga, K.; Watanabe, S.; Yamanaka, Y.; Asou, H.; Ishii, Y.; Satou, K.; Miyota, Y. Dielectric Properties of tissue equivalent liquids in practice. // Tech. Rep. IEICE, No. EMCJ2002-44, (2002), pp. 13-17.

[22] Gabriel, S.; Lau, R. W.; Gabriel, C. The dielectric properties of biological tissues: III. Parametric models for the dielectric spectrum of tissues. // Physics in medicine and biology. 41, 11(1996), pp. 2271. https://doi.org/10.1088/0031-9155/41/11/003

[23] Weiland, T. Time domain electromagnetic field computation with finite difference methods. // International Journal of Numerical Modelling: Electronic Networks, Devices and Fields. 9, 4(1996), pp. 295-319. https://doi.org/10.1002/(SICl)1099-1204(199607)9:4<295::AIDJNM240>3.0.CO;2-8

[24] Faruque, M. R.; Islam, M. T. Design of miniaturized double-negative material for specific absorption rate reduction in human head. // PloS one. 9, 10(2014), Article ID: e109947. https://doi.org/10.1371/journal.pone.0109947

\section{Authors' addresses}

\section{R. I. Faruque}

Space Science Centre (ANGKASA)

Universiti Kebangsaan Malaysia

43600 UKM, Bangi, Selangor, Malaysia

E-mail: rashedgen@yahoo.com

\section{I. Hossain}

Space Science Centre (ANGKASA)

Universiti Kebangsaan Malaysia

43600 UKM, Bangi, Selangor, Malaysia

E-mail: ipk_eee@yahoo.com 